\title{
SPRAWOZDANIE Z SYMPOZJUM POST NETZWERK 18-21 IX 2008 Celje (Słowenia)
}

\author{
Ist die Kirche planbar? Alte Frage - dauernde Ansprüche? \\ Czy da się zaplanować działalność Kościoła? \\ Stare pytanie - trwałe wyzwania
}

Pod powyższym hasłem odbyło się w dniach 18-21 IX 2008 roku w Celje w Słowenii kolejne sympozjum PosT Netzwerk - Stowarzyszenia Pastoralistów Środkowej i Wschodniej Europy. Stowarzyszenie, działające od dwóch lat, już prawnie zarejestrowane, zgromadziło tym razem w Celje około 30 uczestników z siedmiu krajów: stałych już członków i kilka osób, które zostały oficjalnie na tym spotkaniu przyjęte do Stowarzyszenia.

W przebiegu sympozjum można wyróżnić dwie strony: teoretyczną i praktyczną. Tę teoretyczną wypełniły dwa referaty wygłoszone przez ks. prof. Bruno Seveso z Uniwersytetu w Mediolanie, zaproszonego specjalnie na to sympozjum. Pierwszy jego referat nosił dokładnie ten sam tytuł, jakie Stowarzyszenie podjęło jako temat tego sympozjum. Ksiądz prof. Seveso przedstawił sytuację człowieka i Kościoła w ciągle zmieniających się warunkach, które wymagają odpowiedniego działania i podjęcia adekwatnej odpowiedzi. Próby sterowania zastaną rzeczywistością, czyli planowego podejścia, podejmowali już w latach czterdziestych minionego wieku H. Godin i Y. Daniel. Profesor Seveso podkreślił też próby teoretycznego określenia planowania duszpasterskiego przez sławny już Handbuch der Pastoraltheologie. Praktische Theologie der Kirche in ibrer Gegenwart ${ }^{1}$ i pastoralistów niemieckojęzycznych np. w osobie prof. P. M. Zulehnera ${ }^{2}$, jak też ważne sympozja zorganizowane przez Stowarzyszenie Pastoralistów Niemieckich, których przebieg przedstawiono $w$ Pastoraltheologischen Informationen w 1994 i w 2000 roku. Ksiądz prof. B. Seveso przypomniał również o zachęcie papieża Jana Pawła II uczynionej w 1986 roku, aby przygotować plan ewangelizacji Europy. Te wszystkie poczynania wskazują na próby podejmowania planowego kierowania działalnością duszpasterską Kościoła już stosunkowo od dawna.

Planung und Koordination in der Kirche, [w:] F.-X. Arnold i in. (red.), Handbuch der Pastoraltheologie. Praktische Theologie der Kirche in ihrer Gegenwart, Freiburg im Br. 1969, t. IV, s. 603-743.

2 P. M. Zulehner, Pastoraltheologie. Pastorale Futurologie. Kirche auf dem Weg ins gesellschaftliche Morgen, Düsseldorf 1990. 
Czym jest planowanie w Kościele? Profesor Seveso wskazał na ważne kroki, jakie muszą znaleźć się w planowaniu. Kościół powinien mieć jasno wyznaczone priorytety swej działalności, stosownie do aktualnych potrzeb, a także oczekiwań ludzi wobec Kościoła. Tu jednak Kościół powinien mieć przed oczyma przeznaczenie człowieka, czyli uwzględnić odwieczny plan Boga wobec niego, plan zbawienia człowieka przeznaczonego do życia w wieczności (zob. KK 48). Następnie powinna być dogłębnie zbadana aktualna sytuacja społeczeństwa, w którym Kościół żyje i działa. Badania socjologiczne mają tu niepoślednie znaczenie. Kolejnym krokiem będzie podjęcie skoordynowanych i adekwatnych do sytuacji działań. Planowe działanie zawiera więc dwa podstawowe paradygmaty: organizacyjny i praktyczny. Ten drugi paradygmat powinien uwzględniać, według prelegenta, przeszłość, na której bazuje, teraźniejszość, czyli aktualną sytuację i przyszłość, w którą chce się wejść z nowymi pomysłami i rozwiązaniami.

W drugim referacie ks. prof. Bruno Seveso nawiązał do aktualnej sytuacji społeczeństwa $\mathrm{z}$ jego najnowszymi trendami zwanymi postmodernizmem. To społeczeństwo nosi wszelkie znamiona społeczeństwa ryzyka. Jednym z przejawów postmodernizmu jest, według prof. Seveso, realizacja siebie bez społeczności, a nawet niekiedy wbrew wszelkim regułom życia społecznego, aby przede wszystkim realizować siebie samego. Własna biografia jest o wiele ważniejsza niż społeczność, w której się żyje. Charakterystyczne dla postmodernistycznego społeczeństwa ryzyka są prawa człowieka: prawo do nieograniczonej wolności, a więc także wolności od wymagań i zobowiązań; domaganie się praw socjalnych w takim znaczeniu, że społeczność ma zapewnić spełnienie życzeń poszczególnych osób; żądanie praw kulturalnych m.in. mniejszości czy to etnicznych, wyznaniowych, czy też, jak się dzisiaj określa, „inaczej” zachowujących się. Tak zarysowana sytuacja społeczeństwa ryzyka stanowi wyzwanie dla działalności Kościoła. Kościól jednakże powinien tę sytuację uwzględniać w swojej pracy dla dobra człowieka, dla jego zbawienia.

Gdy chodzi o tę stronę, którą nazwaliśmy praktyczną, to były w niej przedstawione sprawozdania z poszczególnych krajów. Sytuację polskiego planowania duszpasterskiego przedstawił ks. dr Szymon Stułkowski z Poznania. Ujął je w trzy wyróżniające się etapy: Wielką Nowennę Tysiąclecia, czas planowania duszpasterskiego za pontyfikatu papieża Jana Pawła II i aktualnie realizujące się programy duszpasterskie w pięcioleciu 2006-2010. Przedstawił też poznański model realizowania programów duszpasterskich zawierający się w hasłach: człowiek (okres Bożego Narodzenia), wspólnota (czas Wielkiego Postu), wiara (okres wielkanocny), kultura (czas w ciągu roku kościelnego).

Kolejne sprawozdanie o planowaniu duszpasterskim Kościoła w Chorwacji przedstawił krótko ks. dr Ivo Dżinicz z uniwersytetu w Djakovie. W jego kraju po bardzo udanym synodzie, nadeszły momenty zmęczenia, a niekiedy cha- 
osu. Postulatem dr. Dżinicza jest właśnie wielka potrzeba planu pastoralnego, który by bazował na postanowieniach synodalnych i porządkował działalność duszpasterską Kościoła w Chorwacji.

Interesującym sprawozdaniem, a właściwie analizą sytuacji Kościoła na Węgrzech, było wystąpienie dr. Akosza Kovacsa z Katolickiego Uniwersytetu Petera Pazmanya. Ukazał on sytuację Kościoła na Węgrzech, jakże bardzo podobną do tej $\mathrm{w}$ wielu krajach postkomunistycznych. Charakteryzuje się ona przejściem od komunizmu do liberalizmu, co on nazwał przejściem od pseudohumanistycznych postaw komunizmu do mylących, a jednocześnie preferowanych przez media półprawd dotyczących życia człowieka. Kościół węgierski charakteryzuje się religijnością ludową, brak zaangażowania inteligencji w życie Kościoła, co wynika ze strachu podjęcia klarownych postaw w obawie przed ostrą krytyką mediów - timor omnium contra omnes. Akosz Kovacs zarzucił węgierskim mediom manipulowanie społecznością, wrogą, niczym nieuzasadnioną postawą wobec Kościoła katolickiego. W społeczeństwie węgierskim jest wiele mniejszości etnicznych, spośród których wyróżnia się mniejszość żydowska, stosunkowo największa w całym świecie. Kościół katolicki na Węgrzech ma wiele do zrobienia w ukazanej tu sytuacji, ale musi się otworzyć na takie społeczeństwo, postulował prelegent, w jakim Kościół żyje, należy być bardziej kreatywnym i aktywnym w społeczeństwie.

Do tej praktycznej strony sympozjum w Celje należy zaliczyć spotkanie $\mathrm{w}$ grupach dyskusyjnych na temat przedstawionych $\mathrm{w}$ referatach i w sprawozdaniach bogatych $w$ treści. W drugim dniu przedstawiano także projekty prowadzonych badań w różnych środowiskach naukowych członków Stowarzyszenia PosT Netzwerk. Ksiądz prof. Josip Baloban z Chorwacji przedstawił badania prowadzone na szczeblu europejskim, a dotyczące wartości, jakimi żyją i jakie reprezentują ludzie, m.in. polityki, małżeństwa, rodziny, stosunków społecznych, emancypacji. W Słowenii zaś dyskutuje się obecnie intensywnie nad tożsamością chrześcijańską i nad jakością życia małżeńskiego i rodzinnego, o czym mówił ks. prof. Pero Aracic z uniwersytetu w Lubljanie. Interesujące działania kościelnopastoralne podejmowane na Węgrzech przedstawił dr Bela Kaposztassy, gdzie angażuje się w promocję laikatu i włączenie go do bardziej aktywnego udziału w odnowę parafii. Wyraża się to także w przygotowaniu akolitów do czynnego ich udziału w życiu parafii.

Przedyskutowano też tematykę na kolejne sympozja, a będą to: duszpasterstwo sakramentalne, Kościół a media i odnowa parafii. Zaprezentowano też owoc spotkań: referatów, wystąpień i artykułów w nowym periodyku Stowarzyszenia pt. Pastoraltheologische Hefte. Periodyk (rocznik) jest redagowany i składany w Polsce w języku niemieckim (język ten jest językiem wszystkich spotkań Stowarzyszenia) przez ks. dr. Mieczysława Polaka z Gniezna przy współpracy dr Teresy Kowalczyk, aktualnie wiceprzewodniczącej PosT Netzwerk. 
Dla uzupełnienia całego sympozjum należy jeszcze wspomnieć spotkanie z miejscowym biskupem Antonem Stressem. Mówił on o problemach jego diecezji, która jest nowo utworzona przed sześciu laty, i której powierzono mu jako ordynariuszowi tworzenie. Nowa diecezja boryka się z problemem braku kapłanów, z sekularyzacją. Ksiądz biskup Stress z całym swoim zespołem doradczym wyznaczył, po szerokiej diecezjalnej dyskusji, jako priorytety działalności duszpasterskiej: rodzinę, młodzież i caritas.

Strona organizacyjna była, można tak powiedzieć, dopracowana w najdrobniejszych szczegółach, co jest zasługą gospodarza sympozjum ks. prof. Pero Aracica. Stworzone warunki dla uczestników sympozjum sprzyjały dobrej atmosferze, a jednocześnie ułatwiały żywy udział tak w dyskusji, jak i w rozmowach kuluarowych.

Oceniając sympozjum w Celje należy je zaliczyć tak od strony merytorycznej, jak i organizacyjnej do bardzo udanych. Wielu spośród uczestników mówiło o nim jako o ubogacającym spotkaniu, na którym treści referatów i dyskusje wnosiły wiele nowego, aktualnego. Podobna sytuacja krajów postkomunistycznych, które znalazły się pod silnym wpływem liberalizmu, zachęca do wzajemnego uczenia się nowej sytuacji, ale też i do podejmowania wspólnych kroków duszpasterskich.

Ks. Mieczysław Olszewski 